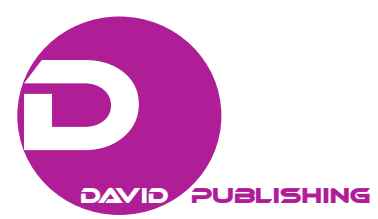

\title{
Organizational Learning as Moderating Variable Between Human Resource Information System and Public Universities' Performance
}

\author{
Hendra Lukito \\ Andalas University, Padang, Indonesia \\ Mohd Fuad Mohd Salleh, Nor Azilah Husin \\ Universiti Selangor, Selangor, Malaysia
}

\begin{abstract}
This study was conducted to see if organizational performance is affected by human resource information system (HRIS) and organizational learning capability. HRIS examined in this study consists of performance appraisal and career management. Data were collected at the public universities located in West Sumatra using questionnaires as the main data collection tool in quantitative approach. Data were analysed using the Statistical Program for Social Science (SPSS). HRIS was measured by using the concept of behavior and found that independent variables significantly related to organizational performance. These results supported that the organizational learning capability as moderating variable influenced the relationship between HRIS and organizational performance. The model stresses the importance of HRIS which supports the organizational performance at public universities. The results of this study indicate that at public universities in West Sumatra, the improvement of HRIS will lead to higher levels of organizational performance. Results of this study are expected to provide benefits to all stakeholders who have an interest in higher education, especially in information technology and performance.
\end{abstract}

Keywords: HRIS, organizational learning capability, organizational performance, university

\section{Introduction}

Changes in science and technology, economic, political, social and cultural, as well as the business environment, are the driving force in creating a more intense competition. The global competition is compelling organizations to develop products and services faster, cheaper and better to sustain competitive advantage in the marketplace. Organizations perform well and create value when it implements strategies that respond to market opportunities by exploiting their internal resources and capabilities (Daud, Abidin, Sapuan, \& Rajadurai, 2011). This fact is creating a great challenge for the organization.

Human resources become the most important production factors, next to skill, land, and capital for the

Hendra Lukito, lecturer at Management Department, Faculty of Economics, Andalas University, Padang, West Sumatra, Indonesia.

Mohd Fuad Mohd Salleh, associate professor and senior lecturer at Faculty of Business, Universiti Selangor, Selangor, Malaysia.

Nor Azilah Husin, associate professor and senior lecturer at Faculty of Business, Universiti Selangor, Selangor, Malaysia.

Correspondence concerning this article should be addressed to Hendra Lukito, Management Department, Faculty of Economics, Andalas University Limau Manis Campus, Padang, West Sumatra, Indonesia. 
organization success in this competition era. At the strategic level, human resources can improve organizational performance and change the way in which organizations are managed (Troshani, Jerram, \& Hill, 2011). Improvement of human resources within an organization can be done through the human resource development. Effective human resource development and its management in an integrated system are expected to improve employee performance, which in turn have an impact on improving organization performance. Any sophisticated equipment used without the support of human resources working in it will not improve organization performance. This statement supports the fact that to improve organization performance, human resources is the dominant factor.

Non-physical factors or intangible assets include technology and organizational learning capability. HRIS is one concept gaining a lot of attention from both academics and practitioners. This concept aims to make human resource management more efficient and effective by utilizing information technology. HRIS as the integrated system uses to gather, share, and analyze information regarding an organization's human resource. HRIS with a variety of definitions but in principle is how to utilize information technology in human resource management not only by making use of hardware and software.

Intangible factors have been increasingly considered to be crucial factors for organizational success, not only in the form of products (services economy), but also as resources and factors influencing processes and decisions of any kind (Pe'rez, Peo'n, \& Orda's, 2005). Technology is one of the valuable intangible assets because it helps the organization to carry out activities more efficiently. Today, almost all production activities depend on the use of technology. The application of technology such as human resource information system (HRIS) can manage human resource management efficiently and effectively. HRIS is a systematic procedure for collecting, storing, maintaining and recovering data required by the organizations about their human resources, personnel activities and organizational characteristics (Altarawneh \& Shqairat, 2010). Whereas Troshani et al. (2011) also in the same opinion defined human resources technologies, such as HRIS as systematic procedures and functions for acquiring, storing, manipulating, retrieving, analyzing, and disseminating pertinent information with the focus on organizational human resources.

Another important intangible asset is organizational learning capability that recently gained not enough attention by both researchers as well as corporate practitioners. Very few studies have attempted to explore further the role of organizational learning capability in both individual and organizational performance (Spicer \& Sadler-Smith, 2006; Rose, Kumar, \& Pak, 2009; Ting, 2012; Vera \& Crossan, 2012; Sisnuhadi \& Nasir, 2013). Learning starts from the employee or individual that then became the new learning organization. Learning process conducted by organization members or the employees will ultimately improve their intellectual abilities. Organizational learning is an effective capability that will offer many benefits to an organization or company, such as creating job satisfaction, preventing turnover and improving organization performance or company. Omiunu (2014) indicated that people in their development and growth depend primarily upon the quality and effectiveness of education system. Thus, this phenomenon attracted the researchers to know more about this intangible asset and its relationship with the Indonesia university performance.

\section{Problem Statement}

Based on the latest 2015 ranking of universities in West Sumatera, Table 1 showed that the region is still far from the position expected from the stakeholders. Currently, Public Universities in West Sumatera are ranked low in the world ranking as well as in Indonesia ranking. 
Table 1

The Rank of University in West Sumatera in 2015

\begin{tabular}{lll}
\hline Name & Indonesia ranking & World ranking \\
\hline Andalas University & 29 & 3,015 \\
Padang State University & 77 & 6,328 \\
The Institute of Islamic Studies (IAIN) Imam Bonjol & n/a & n/a \\
\hline
\end{tabular}

If this situation does not improve, the universities might still be ranked low, and the university would not get good performance, and worst still gain less popularity among potential graduates.

\section{Research Objectives}

The purpose of this study is to investigate the relationship between Human Resource Information System (HRIS) and University Performance. It is also to identify moderating effects of organizational learning capability on the relationships between HRIS and organizational performance at public universities in West Sumatra. To date, little empirical research has been done to investigate the relationships and outcomes of these constructs. This study, therefore, is unique that it has helped to fill this gap to improve our understanding of the role of intangible assets and organizational performance in the Indonesia environment.

\section{Literature Review}

This section reviews the literature to identify the relevant practices comprising organizational performance, HRIS, and organizational learning capability.

\section{Organizational Performance}

In recent years, performance management has come to the fore as organizations seek regularly to optimize their human resources in the face of growing competitive pressures (Suliman, 2000). Rose et al. (2009) stated that the role of performance assessment is helping organization members in managing the value chain. Assessment of organizational performance measurement related to financial and non-financial aspects. Economic indicators alone cannot reflect the complete picture of organizational performances (Ling \& Hung, 2010). Meanwhile, Ling and Hung (2010) believe that organizational performances are the results accomplished by divisions and business units to achieve stage targets or overall goals of an organization. Hanvanich, Sivakumar, Thomas, and Hult (2006) have developed an organizational performance measurement model integrating overall firm performance and innovativeness to assess overall organizational performance. Y. C. Lee and S. K. Lee (2007) find that organizational performance measures strongly influence the behavior of managers and employees and those methods of organizational performance measurement can be categorized into four sections: financial measures, intellectual capital, tangible and intangible benefits, and a balanced scorecard.

\section{Human Resource Information System (HRIS)}

Delorme and Arcand (2010) said that HRIS was an integration of human resource management and information system. HRIS helps human resource managers perform human resource function in a more practical and systematic way using technology. The business environment is growing very fast these days and was followed by technological progress requires each organization to operate efficiently and effectively to gain a sustainable competitive advantage. Public organizations must be able to use information technology in every functional area of the organization such as by implementing HRIS. It is time to say goodbye to the golden age 
of transactional human resource information system and software-payroll and benefits (Sommer, 2006) and hello to the new age of strategic human resources information system and software-performance management, succession planning, base competency compensation and workforce analytics (Greengard, 2005). HRIS is good not only related to the provision of information technology infrastructure which is needed but also is determined by the capabilities of the human resource organization itself. Many obstacles or barrier in the implementation of this concept are due to the unprepared human resource to implement the information system. This phenomenon leads to irregularities in the use of HRIS, as it is a tool of analysis to be merely an instrument for the administration of the course. Much research has been done to provide evidence that the application of HRIS has failed in its implementation because of its and other factors such as the lack of professional vendors. HRIS will make human resource management activities more efficient and effective because the organization will have complete data related to the employees. Then this employee-owned database can be a tool to support decision-making within the organization. The employee database can be used to determine the organization's discretion relating to management such as reception, selection, orientation, performance appraisal, compensations, and employee development.

\section{Organizational Learning Capability}

The consensus in the learning organization literature is that learning at the organizational level is a prerequisite for successful organizational change and performance. Learning could enhance the intellectual capabilities of the employees; as such organizations will eventually be better off through having learned employees. Organizational learning is a dynamic process of creation, acquisition and integration of knowledge aimed at the development of resources and capabilities that contribute to better performance (Kane \& Alavi, 2007). Several organizational researchers have defined learning regarding acquiring, retaining, and transferring knowledge at the individual and group levels (Robey, Boudreau, \& Rose, 2000). In general, the definition of organizational learning as the dynamic process of creating new knowledge and transferring it to where it is needed and used, resulting in the creation of new knowledge for later transfer and use. Knowledge creation, transfer, and retention are the social processes involving communication, interaction, collaboration, and discourse among organizational members. Organizational learning is related to the concept of knowledge management, which is also primarily concerned with the organizations' ability to create and transfer knowledge.

\section{Methodology}

\section{Research Design}

Figure 1 provides the model of conceptual framework of the study based on the variables as discussed in the previous section.

\section{The Relationship Between Organizational Performance and Other Variables}

Organizations should develop HRIS because it will not be easy for competitors to imitate. The synergies resultant from the interactions of technology is the key to the construction of competitiveness. The application of technology to improve the quality of human resources should be conducted on an ongoing basis as changes occur and have an enormous impact on the competencies required by organizations that want to survive in the face of competition. The innovation and learning perspective focus on the intangible assets of an organization mainly on the internal skills and capabilities that are required to support the value creating internal processes 
(Rasula, Vukšić, \& Stemberger, 2012). Application of HRIS is the mean used to increase knowledge/skills of the organization's human resources, which in turn can improve the quality and competence of human resources within the organization. This application makes the organization realize the vision and achieve the medium-term goals and short-term. HRIS and organizational learning show a mix of intangible assets owned and considered able to increase the commitment and competence of members of the organization. In the end, there is an impact on organizational performance improvement, customer satisfaction, job performance and other stakeholders by organizational goals. The perspective of human resource organizations that have the knowledge, abilities, skills and experience that high has contributed significantly to the performance. Also, in the framework of learning and growth measure also emphasizes the importance of competence factors, technological infrastructure, and climate to act in influencing the performance of members of the organization that will ultimately increase productivity. In fact, HRIS and organizational learning positively affect both task performance and the quality of interpersonal relations. The experts demonstrate how learning orientation and organizational learning relates to important organizational outcomes. Individual and organizational learning show significant and positive effects on organizational performance (Kuo, 2011). The finding from the study conducted by Spicer and Sadler-Smith (2006) in small manufacturing firms also indicated that organizational learning had a positive relationship with the financial and non-financial performance of the firms. Similarly many other empirical studies showed positive relationship between organizational learning and performance outcomes (Correa, Morales, \& Pozo, 2007; Ellinger, Ellinger, Yang, \& Howton, 2003; Jimenez \& Navarro, 2006; Khandekar \& Sharma, 2006; Power \& Waddell, 2004; Schroeder, Bates, \& Junttila, 2002).

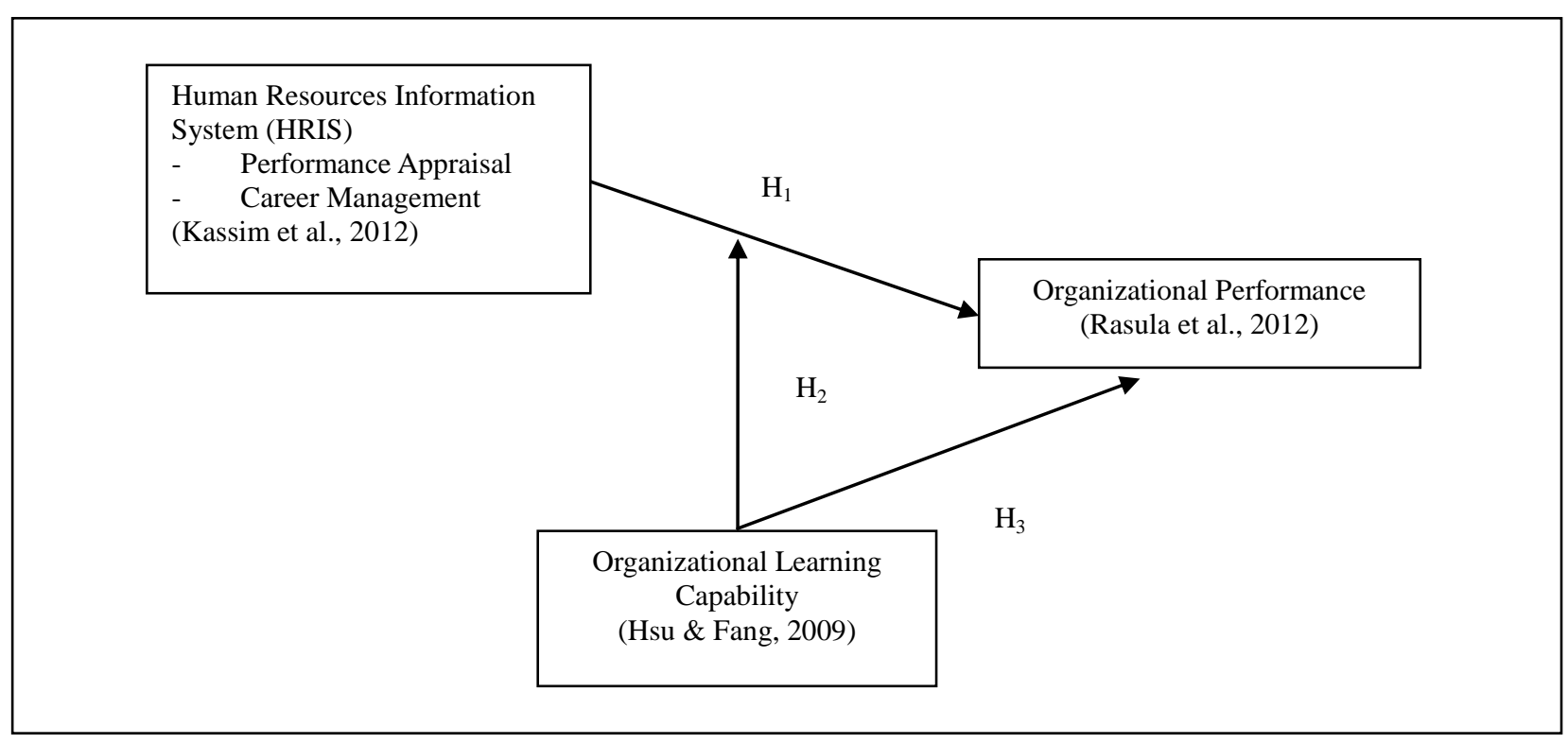

Figure 1. Conceptual framework.

\section{Hypotheses Development}

Based on the literature review and conceptual framework of the study above, then the hypothesis can be stated as follows:

$\mathrm{H}_{1}$ : HRIS has the significant effects on organizational performance of public universities in West Sumatra.

$\mathrm{H}_{2}$ : Organizational learning capability has the significant effects on organizational performance of public universities in West Sumatra. 
$\mathrm{H}_{3}$ : Organizational learning capability moderates the relationship between HRIS and organizational performance of public universities in West Sumatra.

\section{Questionnaire Design}

This research includes the survey research using questionnaires as the main data collections tool and using a quantitative approach. A structured questionnaire is utilized in this study to collect data from faculty members or teaching staff at public universities in West Sumatra. HRIS, organizational learning capability and organizational performance in this study were measured on the attitude scale. Scoring of respondents using the Likert scale is a scale of 5 (five) points or a scale of 1-5 to represent the respondents' opinion.

\section{Analysis and Result}

\section{Sampling}

The selected target population in this study is all lecturers who serve at public universities in West Sumatra. The latest data obtained from all public universities on the number of faculty members are in total 2,707 people. The respondents in this study are permanent lecturers, not under contract or probation at their respective universities. The number of samples used in this study was 338 people (Krejcie \& Morgan, 1970) with a different proportion of respondent for each university. From each university, several questionnaires based on stratifies sampling technique were distributed.

\section{Checking for Normality}

Test of normality. Test for normality in this study using the value of skewness and kurtosis. In this stage, the skewness and kurtosis values of all variables are identified. The results of the skewness and kurtosis values in this study show that all variables both independent and dependent variables had a value between -2 and +2 . Thus, all variables in this study have a normal distribution.

Test of multicollinearity. Testing is done by using the Variance Inflation Factor (VIF), if the VIF value more than 10, then the model used multicollinearity occurs. The results of the VIF values indicate factors in the independent variables in this study have a VIF value less than 10. This result means that the regression model has no multicollinearity between independent variables (Sekaran, 2000).

Test of heteroscedasticity symptom. The picture in Appendix shows the scatterplot of all values of the variables in this study looks at the spread below and above zero and does not form a distinct pattern. Thus, it says that it does not happen heteroscedasticity the research model, so it is worth used to predict the dependent variable based on the independent variables.

Test of linearity. In Appendix it shows the value of linearity significance and significance deviation from linearity for each independent and dependent variables compared with the level of significance $(\alpha=0.05)$. Linearity significance value is less than the degree of significance $(\alpha=0.05)$, and then the linear regression can be used to explain the influence of the variables in this study. Deviation from linearity significance value is greater than the level of significance $(\alpha=0.05$ ); then the linear regression can be used to explain the influence of the variables in this study.

Reliability and validity tests. Legality/validity of a social study results is determined by the measuring instruments used. If the measuring instrument used is not valid or not trustworthy, and then the results obtained will not describe the real situation, it is necessary to address two kinds of tests that are validity test and reliability test to measure the sincerity of the respondents' answers. 
Reliability tests. The results of reliability analysis for each variable in this study can be seen in Appendix. Reliability testing performed using Cronbach's alpha formula. The closer the reliability coefficient to 1.0 is the better. In general, the reliability of less than 0.60 was considered poor reliability, in the range of 0.70 could be accepted, and over 0.80 is good (Nunnally, 1978). Variables used in the study can be said to be reliable or robust is if Cronbach's alpha has more than 0.7.

Validity tests. Valid instrument means the instrument can be used to measure what should be measured. The minimum requirement to be eligible validity is if $r$ count more than 0.3 ( $r$ count $>0.3$ ). So if the $r$ count is greater than 0.3, then the questions in the research instrument are valid (Nunnally, 1978). Based on the results, all questions are valid because each issue has a correlation value ( $r$ count) more than $r$ table (count $>$ table). All questions posed to the respondents qualify the validity of which is that the minimum requirements to be eligible validity are the $r$ count more than 0.3 ( $r$ count $>0.3$ ). So if the $r$ count is greater than 0.3 , then the questions in the research instrument are valid.

\section{Multiple Regressions Analysis}

Multiple regression analysis is used to determine the relationship between the independent variables (HRIS), moderating variable (organizational learning capability) with the dependent variable (organizational performance).

Table 2

Multiple Regression Results on Relationship Between Independent, Moderating and Dependent Variables at Public Universities in West Sumatra

\begin{tabular}{llll}
\hline Variable & \multicolumn{2}{c}{ Coefficients } \\
\cline { 2 - 4 } & Beta $(\beta)$ & $t$ statistics & Significance \\
\hline $\begin{array}{l}\text { Human resource information system } \\
\text { (independent variable } / \mathrm{X}_{1} \text { ) }\end{array}$ & 0.200 & 3.494 & 0.001 \\
$\begin{array}{l}\text { Organizational learning capability } \\
\text { (moderating variable/M) }\end{array}$ & - & - & - \\
$\mathrm{R}^{2}$ & 0.602 & & \\
Adjusted $\mathrm{R}^{2}$ & 0.598 & & \\
F statistic & 162.139 & & \\
Significance of $\mathrm{F}$ & 0.000 & & \\
\hline
\end{tabular}

Based on table above, that the value of $\beta 1$ is 0.200 and $\beta 4$ is 0 points out human resource information system has a positive relationship with organizational performance. The value of $\beta 4$ is 0 because organizational learning capability excludes from stepwise regression model. It means organizational learning capability has not influenced organizational performance. Based on Table $2, \mathrm{R}^{2}$ can be used to measure how far the model's ability to explain variation in the dependent variable (organizational performance). The coefficient of determination in this part is 0.602 or $60.2 \%$ indicating that there is $60.2 \%$ on organizational performance contributed by human resource information system without organizational learning capability. Empirical results are indicating that there are $60.2 \%$ on organizational performance conducted by human resource information system.

The results in Table 2 show that independent variables have a significant relationship with dependent variable. The finding indicates a positive relationship, and this result supports hypothesis $\mathrm{H}_{1}$ by demonstrating a positive relationship between human resource information system and organizational performance. Another analysis is necessary to determine whether there is a real or significant influence of organizational learning 
capability on organizational performance in individual. The statistical program with partial test can use, and the results can be seen in the next part. The result shows that organizational learning capability has not a significantly affected the organizational performance. The results in table above show that moderating variable (organizational learning capability) has no effect on organizational performance. The finding indicates that there is no relationship and this result does not support hypothesis $\mathrm{H}_{2}$ (model 2) by demonstrating that there is not a significant association between moderating and dependent variables at public universities in West Sumatra.

Table 3

Multiple Regression Results on Moderator Effects of Organizational Learning Capability to Relationship Between Independent and Dependent Variables at Public Universities in West Sumatra

\begin{tabular}{|c|c|c|c|c|c|c|}
\hline \multirow{2}{*}{ Variable } & \multicolumn{3}{|c|}{ Coefficients } & \multicolumn{3}{|c|}{ Coefficients } \\
\hline & Beta $(\beta)$ & $t$ statistics & Significance & $\operatorname{Beta}(\beta)$ & $t$ statistics & Significance \\
\hline $\begin{array}{l}\text { Human resource information system } \\
\text { (Independent variable } / \mathrm{X}_{1} \text { ) }\end{array}$ & 0.200 & 3.494 & 0.001 & - & - & - \\
\hline $\begin{array}{l}\text { Organizational learning capability } \\
\text { (Moderating variable/M) }\end{array}$ & - & - & - & - & - & - \\
\hline $\mathrm{X}_{1} \mathrm{M}$ & & & & 0.224 & 3.648 & 0.000 \\
\hline $\mathrm{R}^{2}$ & 0.602 & & & 0.603 & & \\
\hline Adjusted $\mathrm{R}^{2}$ & 0.598 & & & 0.599 & & \\
\hline F statistic & 162.139 & & & 163.022 & & \\
\hline Significance of $\mathrm{F}$ & 0.000 & & & 0.000 & & \\
\hline
\end{tabular}

The results in Table 3 show that moderating variable (organizational learning capability) has significant influences on relationship between human resource information system (independent variable) and organizational performance (dependent variable) at public universities. Moderating relationship exists, if XM is significant. The resulting finding indicates a significant effect and this result supports hypothesis $\mathrm{H}_{3}$ by demonstrating a moderating effect on organizational learning capability to relationship between human resource information systems (independent variable) to organizational performance (dependent variable). The result indicates that organizational learning capability as moderating variable between human resource information system and organizational performance at the five percent significance level $(r<0.05)$. It can be interpreted if organizational learning capability strengthens the relationship between human resource information system with organizational performance at public universities in West Sumatra.

\section{Discussion}

This study purposes to analyze the influence of human resource information system and organizational learning capability on organizational performance at public universities in West Sumatra. The multiple regression analysis with stepwise regression is used. The results in previous parts show that human resource information system as independent variables has a significant relationship with dependent variable. The finding indicates a positive relationship, and this result supports hypothesis $\mathrm{H}_{1}$ by demonstrating a positive relationship between organizational learning capability and organizational performance. This paper has the objective to analyze the influence of organizational learning capability on organizational performance. The finding indicates there is no relationship and this result does not support hypothesis $\mathrm{H}_{2}$ by demonstrating that there has no significant association between moderating and dependent variables at public universities in West Sumatra. 
This research objective is also to explain the impact of organizational learning capability as moderating variable on a relationship between human resource information system and organizational performance. The results show that moderating variable (organizational learning capability) has significant influences in relationship between human resource information system (independent variable) and organizational performance (dependent variable) at public universities. The resulting finding indicates a significant effect and this result supports hypothesis $\mathrm{H}_{3}$ by demonstrating a moderating effect on organizational learning capability to the relationship between human resource information system (independent variable) and organizational performance (dependent variable). It can be interpreted that organizational learning capability strengthens the relationship between human resource information system with organizational performance at public universities in West Sumatra.

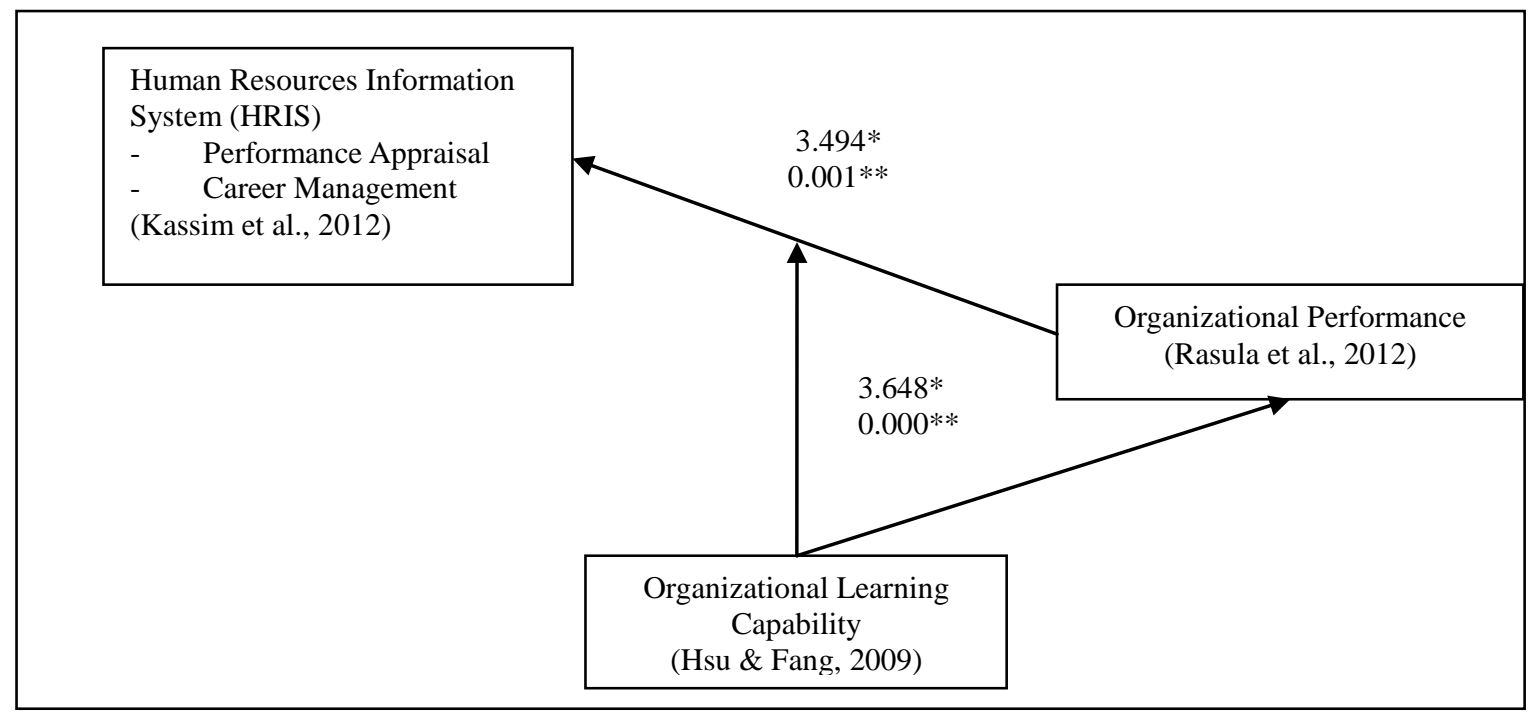

Figure 2. Moderating effect on the relationship between independent and dependent variables.

$*=t$ statistic; $* *=$ significance of $t(\alpha=0.05)$.

\section{Conclusion and Recommendation}

The rapid growth of service industries and the increased global competition, particularly in higher education institutions, had meant that the need for different controls and performance measures has attracted much attention. However, researchers are finding it difficult to measure university performance because of the intangible nature of the products and services of the higher education industry. The interpretation of this study is a starting point for other research.

Researchers have same views about the impact of human resource information system and organizational learning capability on organizational performance with other investigators (Rose, Kumar, \& Pak, 2009; Kuo, 2011; Rasula et al., 2012; Vera \& Crossan, 2012). In conclusion, the impact of technology and learning on performance is essential to improve organizational performance. Technology and learning capability become a source of competitive advantage for organization if it matches with the business strategy.

Perhaps, all top management in West Sumatera Public University should find ways and means to enhance their HRIS to the optimum level so that they can improve their university performance and thus be listed a better and higher Indonesia as well as world ranking university in a near future. This study has addressed a significant gap in human resource information system and organizational performance literature. This is done by formulating, examining, and establishing a research model linking the multidimensional and moderating 
effects of organizational learning capability on relationships between human resource information system and organizational performance as shown in Figure 2.

The results of this study indicate that at public universities in West Sumatra, the use of technology will be led to higher levels of organizational performance. The presence of organizational learning induces higher levels of organizational performance. The moderating analysis affirms that in West Sumatra public universities, organizational learning capability does moderate the relationship between human resource information system and organizational performance.

The data were collected in West Sumatra the characteristics of the universities surveyed may be different from those in other areas or regions. Hence, the present results should not be assumed to represent the general case. However, it may provide a fundamental reference for the universities located in other areas or regions whose environments are similar to those in West Sumatra. This would provide the basis for generalization because Indonesia is composed of many parts which have a culture, customs behavior and different ethnic.

Method of data analysis in this study uses a statistical model with the statistical program latest versions of SPSS. Future research using other statistical analyses could confirm the findings of this study. Structural equation modeling (SEM) technique i.e. SmartPLS can be adopted to test hypotheses and investigate the nature of association between independent variable (intangible assets) and dependent variable (organizational performance).

This study uses organizational learning capability as a moderating variable, future study may try to examine other moderating variables in the relationship between knowledge management, intellectual capital, human resources information system and organizational performance, increasing our understanding of how intangible assets affects to organizational performance. Researcher has proposed the co-alignment between a firm's learning/knowledge strategy as a moderator of the impact of learning and knowledge/intellectual capital on performance.

This research is quantitative by analyzing the influence of intangible assets consisting of knowledge management, intellectual capital, human resource information system and organizational learning capability on organizational performance. A similar study can be conducted using qualitative that may uncover some new findings that would strengthen the finding of previous studies. In particular, qualitative studies can examine intangible assets within organizations of different cultures which offer the potential to gain deeper insight into the phenomenon that have been presented in this study.

\section{References}

Altarawneh, I., \& Al-Shqairat, Z. (2010). Human resource information systems in Jordanian Universities. International Journal of Business and Management, 5(10), 113-127.

Correa, F. A. A., Morales, V. J. G., \& Pozo, E. C. (2007). Leadership and organizational learning's role on innovation and performance: Lessons from Spain. Industrial Marketing Management, (36).

Daud, S., Abidin, N., Sapuan, N. M., \& Rajadurai, J. (2011). Enhancing university business curriculum using an importance-performance approach: A case study of the business management faculty of a university in Malaysia. International Journal of Educational Management, 25(6), 545-569.

Delorme, M., \& Arcand, M. (2010). HRIS implementation and deployment: A conceptual framework of the new roles, responsibilities and competences for HR professionals. International Journal of Business Information Systems, 5(2), $148-161$.

Ellinger, A. D., Elinger, A. E., Yang, B., \& Howton, S. W. (2003). Making the business case for the learning organization concept: The problem and the solution. Advances in Developing Human Resources, 5(2).

Greengard, S. (2005). Putting it all together. Workforce Management, 83(11), 6-10.

Hanvanich, S., Sivakumar, K., Thomas, G., \& Hult, M. (2006). The relationship of learning and memory with organizational performance: The moderating role of turbulence. Journal of the Academy of Marketing Science, 34(4). 
Hsu, Y. H., \& Fang, W. (2009). Intellectual capital and new product development performance: The mediating role of organizational learning capability. Technological Forecasting and Social Change, 76, 664-677.

Jimenez, D. J., \& Navarro, J. G. C. (2006). The performance effect of organizational learning and market orientation. Industrial Marketing Management, 36(6).

Kane, G. C., \& Alavi, M. (2007). Information technology and organizational learning: An investigation of exploration and exploitation processes. Organization Science, 18(5).

Kassim, N. Md., Ramayah, T., \& Kurnia, S. (2012). Antecedents and outcomes of human resource information system (HRIS) use. International Journal of Productivity and Performance Management, 61(6), 603-623.

Khandekar, A., \& Sharma, A. (2006). Organizational learning and performance: Understanding Indian scenario in present global context. Education and Training, 48 (8/9).

Krejcie, R. V., \& Morgan, D. W. (1970). Determining sample size for research activities. Educational and Psychological Measurement.

Kuo, T, -H. (2011). How to improve organizational performance through learning and knowledge? Journal of Manpower, 32(5/6), 581-603.

Lee, Y. C., \& Lee, S. K. (2007). Capability, processes, and performance of knowledge management: A structural approach. Human Factors and Ergonomics in Manufacturing, 17(1).

Ling, Y.-H., \& Hung, L. (2010). How intellectual capital management influences organizational performances: Intellectual capital as a mediating variable. Journal of Human Resource Management, 1(10), 1-27.

Nunnally, J. C. (1978). Psychometric theory (2nd ed.). New York, NY: McGraw-Hill.

Omiunu, O. G. (2014). Enhancing human capital efficiency in the Nigeria educational sector. Journal of Education and Practice, 5(14), 69-73.

Pe'rez, L. S., Peo'n, J. M. M., \& Orda's, C. J. V. (2005). Organizational learning as a determining factor in business performance. The Learning Organization, 12(3), 227-245.

Power, J., \& Waddell, D. (2004). The link between self-managed work teams and learning organizations using performance indicators. The Learning Organization, 11(2/3).

Rašula, J., Vukšić, V., \& Stemberger, M. I. (2012). The impact of knowledge management on organisational performance. Economic and Business Review, 14(2), 147-168.

Robey, D., Boudreau, M. C., \& Rose, G. M. (2000). Information technology and organizational learning: A review and assessment of research. Accounting Management Information Technology Journal.

Rose, R. C., Kumar N., \& Pak, O. G. (2009). The effect of organizational learning on organizational commitment, job satisfaction and work performance. The Journal of Applied Business Research, 25(6), 55-66.

Saeed, R., Sami, A., Lodhi, R. N., \& Iqbal, A. (2013). Intellectual capital and organizational performance: An empirical study in telecom sector of Pakistan. Middle East Journal of Scientific Research, 18(7), 926-932.

Schroeder, R. G., Bates, K. A., \& Junttila, M. A. (2002). A resource-based view of manufacturing strategy and the relationship to manufacturing performance. Strategic Management Journal, 23.

Sekaran, U. (2000). Research methods for business: A skill-building approach (3rd ed.). John Wiley \& Sons, Inc.

Sekaran, U., \& Bougie, R. (2010). Research methods for business: A skill-building approach (5th ed.). A John Wiley \& Sons, Ltd.

Sisnuhadi, \& Nasir, J. A. (2013). The role of organizational learning in the relationship between quality management practices and organizational performance. Interdisciplinary Journal of Contemporary Research in Business, 4(9), 72-92.

Sommer, B. (2006). Divergence or alignment: State of HR and HR technology. IHRIM Global Conference-Boston, MA.

Spicer, D. P., \& Sadler-Smith, E. (2006). Organizational learning in smaller manufacturing firms. International Small Business Journal, 24(2).

Suliman, A. M. (2000). The multi-dimensional nature of organisational commitment in a non-western context. Journal of Management Development, 19(1).

Ting, K. S. (2012). How accumulation of intellectual capital of ic design firms listed in taiwan impacts organization performance: Organizational learning capability as the mediator. The Journal of Global Business Management, 8(1), 62-73.

Troshani, I., Jerram, C., \& Hill, S. R. (2011). Exploring the public sector adoption of HRIS. Industrial Management \& Data Systems, 111(3), 470-488.

Vera, D., \& Crossan, M. (2012). Organizational learning, knowledge management, and intellectual capital: An integrative conceptual model. The Blackwell Handbook of Knowledge Management and Organizational Learning, Blackwell Publish England, Oxford, UK, 1-25. 


\section{Appendix}

Skewness and kurtosis statistics

\begin{tabular}{llll}
\hline Number & Variable & Skewness value & Kurtosis value \\
\hline 1 & Human resource information system $\left(\mathrm{X}_{1}\right)$ & -1.140 & 1.987 \\
2 & Organizational learning capability $\left(\mathrm{X}_{2}\right)$ & -0.651 & 0.762 \\
3 & Organizational performance $(\mathrm{Y})$ & -0.870 & 0.673 \\
\hline
\end{tabular}

Test of multicollinearity

\begin{tabular}{lll}
\hline Number & Variable & VIF \\
\hline 1 & Human resource information system $\left(\mathrm{X}_{3}\right)$ & 2.643 \\
2 & Organizational learning capability $\left(\mathrm{X}_{4}\right)$ & 2.094 \\
\hline
\end{tabular}

\section{Scatterplot}

\section{Dependent Variable: $Y$}

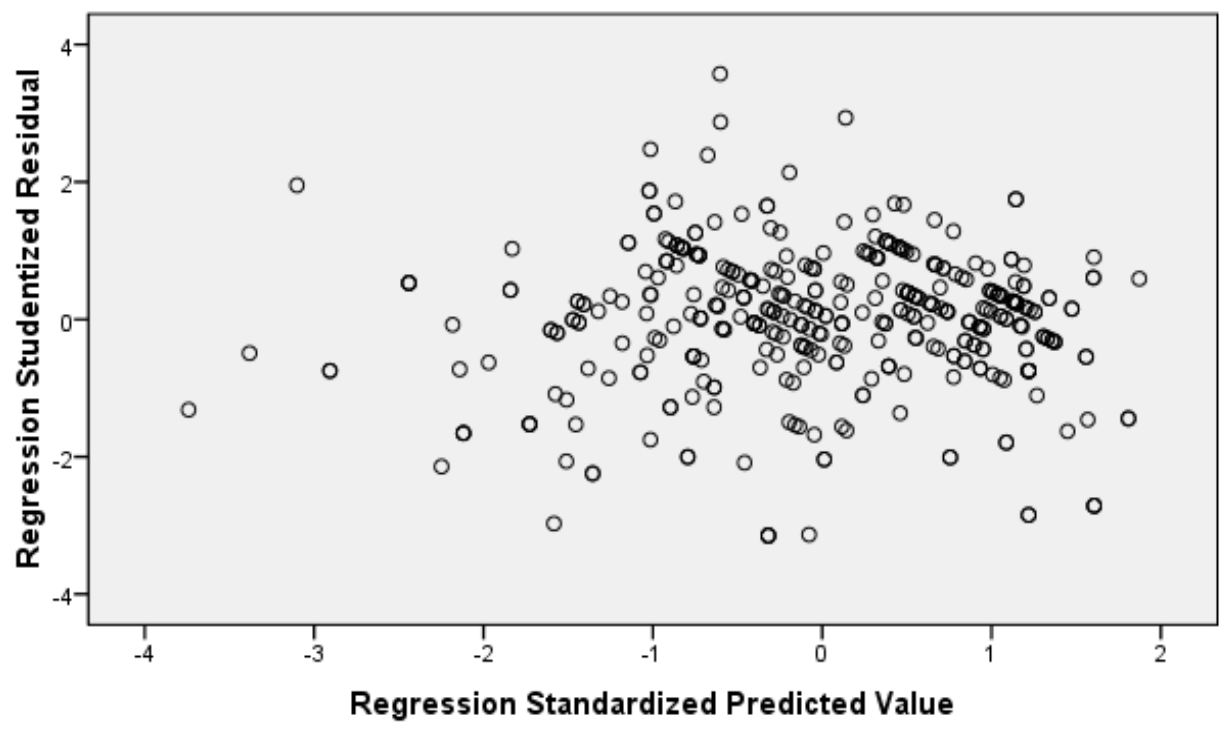

$\mathrm{Y} * \mathrm{X}_{1}$

\begin{tabular}{|c|c|c|c|c|c|c|c|}
\hline \multicolumn{8}{|c|}{ ANOVA table } \\
\hline & & & Sum of squares & df & Mean square & $\mathrm{F}$ & Sig. \\
\hline \multirow{5}{*}{$\mathrm{Y} * \mathrm{X}_{1}$} & \multirow{3}{*}{$\begin{array}{l}\text { Between } \\
\text { groups }\end{array}$} & (Combined) & 54.528 & 29 & 1.880 & 13.865 & 0.000 \\
\hline & & Linearity & 43.477 & 1 & 43.477 & 320.597 & 0.000 \\
\hline & & Deviation from linearity & 11.050 & 28 & 0.395 & 2.910 & 0.000 \\
\hline & \multicolumn{2}{|c|}{ Within groups } & 50.177 & 370 & 0.136 & & \\
\hline & \multicolumn{2}{|l|}{ Total } & 104.705 & 399 & & & \\
\hline \multicolumn{8}{|c|}{ Measures of association } \\
\hline & \multicolumn{3}{|r|}{ R squared } & Eta & \multicolumn{3}{|c|}{ Eta squared } \\
\hline $\mathrm{Y} * \mathrm{X}_{1}$ & & 0.644 & 0.415 & 0.722 & \multicolumn{3}{|c|}{0.521} \\
\hline
\end{tabular}




\begin{tabular}{|c|c|c|c|c|c|c|c|}
\hline \multicolumn{8}{|c|}{ ANOVA table } \\
\hline & & & Sum of squares & df & Mean square & $\mathrm{F}$ & Sig. \\
\hline \multirow{5}{*}{$\mathrm{Y} * \mathrm{M}$} & \multirow{3}{*}{$\begin{array}{l}\text { Between } \\
\text { groups }\end{array}$} & (Combined) & 45.296 & 16 & 2.831 & 18.251 & 0.000 \\
\hline & & Linearity & 33.587 & 1 & 33.587 & 216.527 & 0.000 \\
\hline & & Deviation from linearity & 11.709 & 15 & 0.781 & 5.032 & 0.000 \\
\hline & \multicolumn{2}{|c|}{ Within groups } & 59.409 & 383 & 0.155 & & \\
\hline & \multicolumn{2}{|c|}{ Total } & 104.705 & 399 & & & \\
\hline \multicolumn{8}{|c|}{ Measures of association } \\
\hline & \multicolumn{3}{|r|}{ R squared } & Eta & \multicolumn{3}{|c|}{ Eta squared } \\
\hline $\mathrm{Y} * \mathrm{M}$ & & 0.566 & 0.321 & 0.658 & \multicolumn{3}{|c|}{0.433} \\
\hline
\end{tabular}

Test of validity and reliability for Human Resource Information System (HRIS) (X

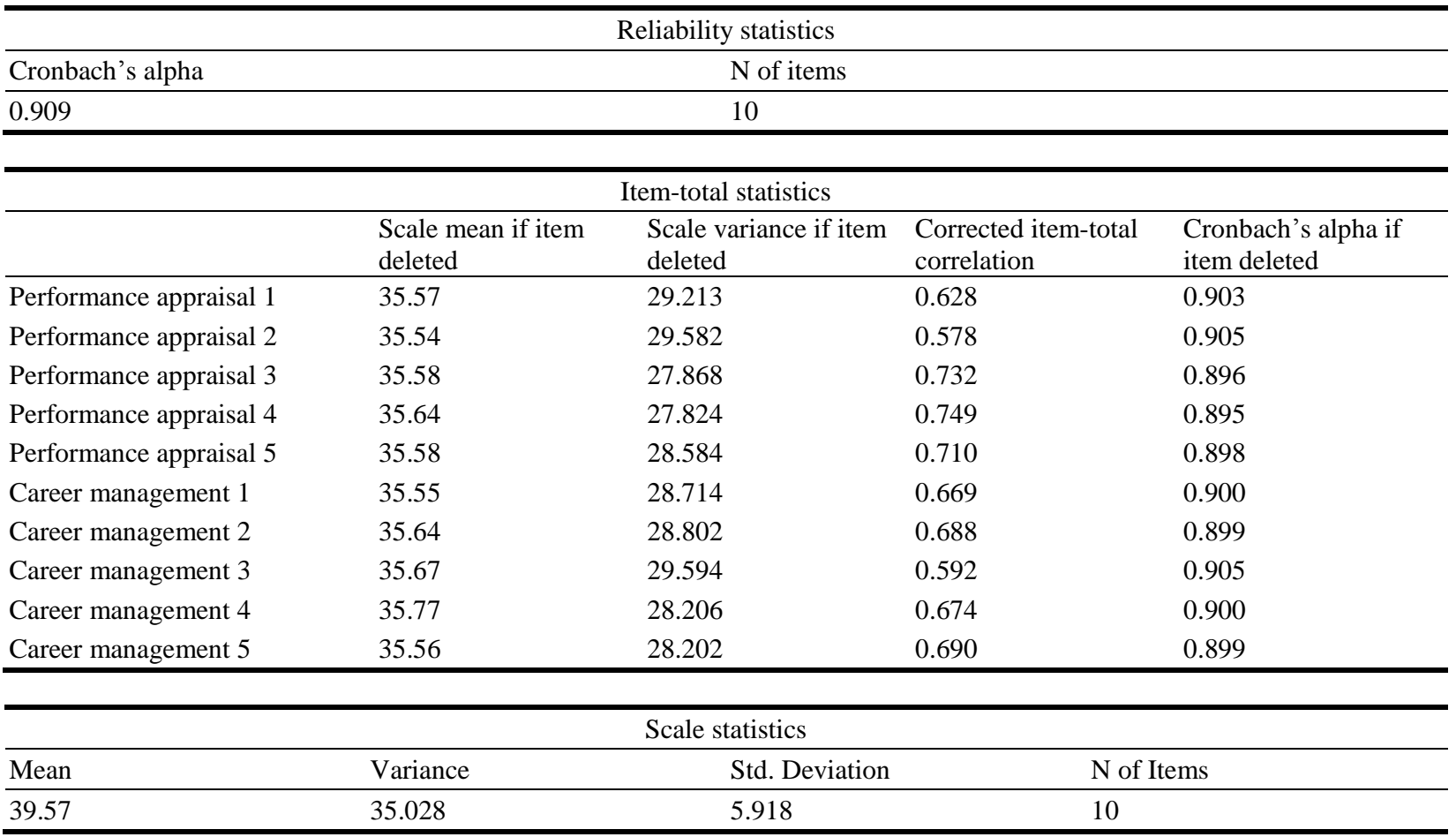

Test of validity and reliability for Organizational Learning Capability (M)

\begin{tabular}{|c|c|c|c|c|}
\hline \multicolumn{5}{|c|}{ Reliability statistics } \\
\hline Cronbach's Alpha & \multicolumn{3}{|c|}{$\mathrm{N}$ of Items } & \\
\hline 0.834 & \multicolumn{3}{|c|}{5} & \\
\hline \multicolumn{5}{|c|}{ Item-total statistics } \\
\hline & $\begin{array}{l}\text { Scale mean if item } \\
\text { deleted }\end{array}$ & $\begin{array}{l}\text { Scale variance if } \\
\text { item deleted }\end{array}$ & $\begin{array}{l}\text { Corrected item-total } \\
\text { correlation }\end{array}$ & $\begin{array}{l}\text { Cronbach's alpha if } \\
\text { item deleted }\end{array}$ \\
\hline Organizational learning capability 1 & 15.76 & 5.962 & 0.598 & 0.810 \\
\hline Organizational learning capability 2 & 15.94 & 5.389 & 0.605 & 0.811 \\
\hline Organizational learning capability 3 & 15.75 & 5.383 & 0.677 & 0.788 \\
\hline Organizational learning capability 4 & 15.73 & 5.443 & 0.701 & 0.782 \\
\hline Organizational learning capability 5 & 15.77 & 5.759 & 0.597 & 0.810 \\
\hline
\end{tabular}


Test of validity and reliability for Organizational Performance (Y)

\begin{tabular}{|c|c|c|c|c|}
\hline \multicolumn{5}{|c|}{ Reliability statistics } \\
\hline Cronbach's alpha & \multicolumn{3}{|c|}{$\mathrm{N}$ of items } & \\
\hline 0.848 & \multicolumn{3}{|c|}{10} & \\
\hline \multicolumn{5}{|c|}{ Item-total statistics } \\
\hline & $\begin{array}{l}\text { Scale mean if item } \\
\text { deleted }\end{array}$ & $\begin{array}{l}\text { Scale variance if } \\
\text { item deleted }\end{array}$ & $\begin{array}{l}\text { Corrected item-total } \\
\text { correlation }\end{array}$ & $\begin{array}{l}\text { Cronbach's alpha if } \\
\text { item deleted }\end{array}$ \\
\hline Organizational performance 1 & 35.89 & 21.866 & 0.504 & 0.838 \\
\hline Organizational performance 2 & 35.82 & 22.205 & 0.509 & 0.837 \\
\hline Organizational performance 3 & 35.75 & 20.673 & 0.660 & 0.823 \\
\hline Organizational performance 4 & 35.66 & 21.848 & 0.534 & 0.835 \\
\hline Organizational performance 5 & 35.71 & 21.786 & 0.555 & 0.833 \\
\hline Organizational performance 6 & 35.70 & 22.206 & 0.501 & 0.838 \\
\hline Organizational performance 7 & 35.85 & 22.006 & 0.489 & 0.839 \\
\hline Organizational performance 8 & 36.02 & 21.065 & 0.554 & 0.833 \\
\hline Organizational performance 9 & 35.80 & 20.458 & 0.647 & 0.824 \\
\hline Organizational performance 10 & 35.56 & 22.042 & 0.510 & 0.837 \\
\hline
\end{tabular}

